\title{
$\beta$-Adrenergic receptor concentration and subtype in the corpus luteum of the adult pseudopregnant rat
}

\author{
E. Norjavaara, S. Rosberg, M. Gåfvels*, B-M. Boberg and G. Selstam* \\ Department of Physiology, University of Göteborg, PO Box 33031, S-40033 Göteborg, Sweden; and \\ *Department of Physiology, University of Umeå, PO S-90187 Umeå, Sweden
}

\begin{abstract}
Summary. Luteal $\beta$-adrenergic receptor concentration and subtype were determined in adult pseudopregnant rats during and after the period of the functional luteal phase. The specific $\beta$-adrenergic receptor ligand $(-)-3-\left[{ }^{125} \mathrm{I}\right]$ iodocyanopindolol ( $\left.\left({ }^{125} \mathrm{I}\right] \mathrm{ICYP}\right)$ was used to determine the receptor concentration in corpora lutea of adult pseudopregnant rats. A 3 -fold increase in $\beta$-adrenergic receptor concentration was seen during the first 2-3 days of pseudopregnancy, whereafter the receptor concentration declined. During the functional luteal regression period (Day 12-15) the receptor levels were still low. In regressed (Day 16-22) corpora lutea a temporary increase in $\beta$-receptor concentration was seen which may represent some role for $\beta$-adrenergic mechanisms in the regulation of morphological regression in the corpus luteum.

To determine the $\beta$-adrenergic subtype, competition of $\left[{ }^{125}\right.$ I]ICYP-binding with selective $\beta_{1}$ - and $\beta_{2}$-adrenergic antagonists was assessed in corpora lutea of different ages and in rat heart and uterus. The $\beta$-adrenergic receptors in corpora lutea of adult pseudopregnant rats were shown to be solely of the subtype $\beta_{2}$, regardless of the luteal age.
\end{abstract}

Keyw'ords: $\beta$-adrenergic receptor; subtype; corpora lutea; rat; luteal phase

\section{Introduction}

Various aspects of the response to catecholamines and $\beta$-adrenergic agonists have been investigated for the corpus luteum of the rat (e.g. Harwood et al., 1980; Azhar \& Menon, 1981; Norjavaara $e t$ al., 1982, 1983; Selstam et al., 1985; Rosberg et al., 1986; Selstam et al., 1987). Adrenaline from adrenals and noradrenaline from ovarian sympathetic nerve endings have been suggested to have a luteotrophic function in the corpus luteum of the rat (Norjavaara, 1984). A key to understanding the role of catecholamines as presumptive luteotrophic factors is the receptor binding characteristics. For the rat corpus luteum, studies of this kind have only been performed in corpus luteum models in which pseudopregnancy was induced in immature rats with PMSG, alone or in combination with hCG. For the Parlow model, in which immature rats are treated with a high dose of PMSG and later followed by hCG to luteinize the ovaries, McIlroy \& Bergert (1984) reported that the $\beta$-adrenergic receptor concentration of luteinized ovaries increased up to 6 days after the hCGtreatment and thereafter remained high. We have used the PMSG ovulatory model, in which immature rats are treated with a single moderate dose of PMSG, which induces follicular maturation and ovulation with a fairly physiological number of ovulations. In this model, the luteal content of $\beta$-adrenergic receptors increased rapidly, maximal levels were seen 1-3 days after ovulation, and thereafter the concentration decreased (Norjavaara et al., 1984). The discrepancy between these two rat models led us to study the $\beta$-adrenergic receptor concentration in a more physiological model, the adult pseudopregnant rat, in which follicular maturation, ovulation, luteinization as well as the luteotrophic support are completely regulated by endogenous factors. A 
second advantage is that the luteal phase is not connected with the development of puberty, since the pseudopregnancy is induced in sexually mature rats.

We have now studied the kinetics and content of the $\beta$-adrenergic receptors as well as the relative proportions between receptors of subtypes $\beta_{1}$ and $\beta_{2}$. Furthermore, since the fate of the $\beta$-adrenergic receptor at the start and beyond the luteolytic period is unknown, we have followed the fate of the $\beta$-adrenergic receptor over this period.

\section{Materials and Methods}

\section{Hormones and chemicals}

Pregnant mare's serum gonadotrophin (PMSG) and L-isoproterenol were purchased from Sigma (St Louis, MO, USA). Alprenolol and metoprolol were gifts from AB Hässle (Mölndal, Sweden), zinterol was a gift from BristolMyers company (Evansville, Indiana, USA), phentolamine a gift from Ciba-Geigy Läkemedel AB (Västra Frölunda, Sweden) and betaxolol a gift from G. D. Searle AB (Malmö, Sweden). (-)-3-[125 I]Iodocyanopindolol ([125 I]ICYP, sp. act. $2000 \mathrm{Ci} / \mathrm{mmol}$ ) was purchased from Amersham International (Buckinghamshire, UK). GTP was purchased from Boehringer-Mannheim (Mannheim, West Germany). All other chemicals were of analytical grade and purchased from Merck (Darmstadt, West Germany) or Sigma.

\section{Animals}

Immature and cyclic female rats of the Sprague-Dawley strain were purchased from ALAB (Stockholm, Sweden). They were kept in the local animal house and maintained under constant temperature $\left(27^{\circ} \mathrm{C}\right)$ and humidity $(60 \%)$ with light period from 05:00 to 19:00 h.

\section{Rat ovulatory models}

Adult pseudopregnancy. To obtain pseudopregnancy in adult cyclic female rats, 3-4 rats (body weight 225-300 g) were mated with a vasectomized sterile male rat. Day 1 of pseudopregnancy was defined as the day when a vaginal plug was recovered. The length of the pseudopregnancy was 12-14 days as judged from plasma steroid concentrations and vaginal smears (Norjavaara et al., 1987).

PMSG. Immature rats were injected s.c. with a single dose of 8 i.u. PMSG (Sigma) in the morning (08:00-09:30 h) when the rats were 26 days old. This treatment induces follicular maturation, which induces, in the afternoon of Day 28 , a preovulatory endogenous surge of gonadotrophins, resulting in ovulation early in the morning (around 02:00 h) of Day 29 and formation of corpora lutea. Day 1 of pseudopregnancy was defined as the day of corpus luteum formation. The length of the luteal phase is 10-12 days (Norjavaara et al., 1984).

\section{Dissection procedure}

Ovaries were excised from the rats, dissected free from adnexal tissues on filter paper and corpora lutea of pseudopregnancy were extirpated under a stereomicroscope, frozen on solid $\mathrm{CO}_{2}$ and kept at $-80^{\circ} \mathrm{C}$ until analysis. Analyses were performed within 2 months.

Since the ovaries from adult pseudopregnant rats contain corpora lutea from earlier oestrous cycles, the corpora lutea of pseudopregnancy were distinguished by the following criteria.

Day 1-3: the newly formed corpora lutea were paler and had a more loose structure, as well as a more distinct vascular network around the ovulatory point, compared to corpora lutea of earlier oestrous cycles.

Day 4-8: these corpora lutea were larger in size and more reddish than corpora lutea of earlier oestrous cycles.

Day 9-14: these corpora lutea were larger in size and slightly more reddish than corpora lutea of earlier oestrous cycles. A few larger vessels were seen over the surface.

Day 15-22: these corpora lutea were identified principally by the same criteria as for those from Day 9-14, with the difference that more large vessels were seen.

We have earlier used these criteria to obtain corpora lutea on Days 1 to 14 of pseudopregnancy in adult rats for in-vitro studies and found that in-vitro progesterone synthesis by the isolated corpora lutea follows the plasma progesterone concentrations (Gåfvels et al., 1987), thus giving strong support for the correctness of these criteria.

Corpora lutea of the PMSG-treated rats are easily distinguished since they all belong to the same and only generation and were dissected and treated as above.

Whole heart and uterus were dissected from PMSG-treated rats on Day 3 and treated as above. 


\section{Membrane preparation}

Corpora lutea of pseudopregnancy from $2-4$ rats were homogenized with an all-glass Dounce homogenizer (15-20 strokes with the tight pestle) in $2.5 \mathrm{ml}$ ice-cold Tris-sucrose buffer ( $10 \mathrm{~mm}$-Tris and $1 \mathrm{~mm}$-EDTA, pH 7.5 with $27 \%$ sucrose). The homogenizer was washed twice with $2 \mathrm{ml}$ Tris sucrose. The homogenate obtained was centrifuged for $5 \mathrm{~min}$ at $160 \mathrm{~g}$ at $4^{\circ} \mathrm{C}$. The supernatant was filtered through 2 layers of cheese cloth and centrifuged for $50 \mathrm{~min}$ at $20000 \mathrm{~g}$. The supernatant was discarded and the membrane pellet resuspended in Tris sucrose buffer with the help of the Dounce homogenizer. To obtain membranes from heart and uterus the same procedure was performed.

\section{Determination of $\beta$-adrenergic receptor concentration}

To $100 \mu \mathrm{l}$ samples of the resuspended membranes (corresponding to $25-75 \mu \mathrm{g}$ protein), different concentrations of $\left[{ }^{125} \mathrm{I}\right] \mathrm{ICYP}(\mathrm{I} \cdot 5-200 \mathrm{pM})$ were added in $100 \mu \mathrm{T}$ Tris buffer. Alprenolol $(10 \mu \mathrm{M})$ was used to determine non-specific binding. GTP $(50 \mu \mathrm{M})$, phentolamine $(100 \mu \mathrm{M})$ and ascorbic acid $(1.1 \mathrm{~mm})$ were present in all test tubes. All preparations were performed on ice $\left(4^{\circ} \mathrm{C}\right)$ and the reaction was started by transferring the tubes from ice to room temperature $\left(22^{\circ} \mathrm{C}\right)$. The binding increased with incubation time up to $60-90 \mathrm{~min}$ and thereafter was constant: incubation for $120 \mathrm{~min}$ was therefore used for the present binding studies. The reaction was stopped by addition of $3 \mathrm{ml}$ ice-cold Tris buffer followed by immediate separation of bound and free [ ${ }^{125}$ I]ICYP by filtration and washing ( 5 times with $3 \mathrm{ml}$ ice-cold Tris buffer) on Whatman GF/C filters under vacuum. The filters were counted for radioactivity in a Gammacounter (Packard Autogamma). For each concentration of [ ${ }^{125}$ I]ICYP (6 concentrations/assay; 12.5-200 pM) duplicate samples were taken for specific and non-specific binding, respectively. Total and non-specific binding on the ligand were linear at least up to about $150 \mu \mathrm{g}$ of luteal membrane protein.

\section{Competition of [ $^{125}$ IJICYP binding with betaxolol, metoprolol and zinterol}

Samples $(100 \mu \mathrm{l})$ of the resuspended membranes were mixed with $100 \mu]\left[{ }^{125} \mathrm{I}\right] \mathrm{ICYP}(100 \mathrm{pmM})$ with GTP $(50 \mu \mathrm{M})$, phentolamine $(100 \mu \mathrm{M})$, ascorbic acid $(1.1 \mathrm{mM})$ and $100 \mu \mathrm{l}$ of the respective antagonist $(10 \mathrm{pM}-300 \mu \mathrm{M})$ (all final concentrations). All preparations were performed on ice and the binding reaction was started by transferring the test tubes to room temperature $\left(22^{\circ} \mathrm{C}\right)$. The incubation time was $120 \mathrm{~min}$ and the reaction was stopped as described above.

\section{Determination of proteins}

Membrane samples were precipitated in $2 \mathrm{ml}$ ice-cold $10 \%$ trichloroacetic acid overnight and centrifuged $(20 \mathrm{~min}$, $2000 \mathrm{~g}$ ). The protein precipitate was redissolved in $500 \mu \mathrm{l} 1 \mathrm{M}-\mathrm{NaOH}$ and aliquants were taken for determination of protein content according to Lowry et al. (1951), using bovine serum albumin as standard.

\section{Data analysis}

The $\beta$-adrenergic receptor concentration was calculated by fitting the binding data with non-linear regression to a single binding site function (McIntosh \& McIntosh, 1980). The binding-competition curves were further analysed by fitting the data to a two-component binding function as described by DeLean et al. (1980). A two binding site model was rejected when the residual variance was not significantly reduced (F-test) compared to the one binding site model. The $K_{\mathrm{i}}$ values were calculated from the $\mathrm{IC}_{50}$ values according to Cheung \& Prusoff (1973). Differences between treatment groups were tested with analysis of variance (ANOVA) followed by the Student-Newman-Keuls multiple range test (Woolf, 1968).

\section{Results}

On Day 2-4 of pseudopregnancy in adult rats, the luteal content of $\beta$-adrenergic receptors was at its highest, $\sim 3$ times higher than in the newly formed corpora lutea (Day 1) and also higher than later on during pseudopregnancy (Day 5-14) (Fig. 1). As shown in Table 1, the $K_{d}$ values for $\left[{ }^{125} I\right] I C Y P$ binding did not change during pseudopregnancy. The $\beta$-adrenergic receptor concentration in corpora lutea during functional luteolysis (Day 12-15) was low. However, after luteolysis (the postluteolytic period Day 16-22) the luteal content of $\beta$-adrenergic receptors increased 2-3-fold compared to the end of pseudopregnancy (Fig. 1; Table 1). Preliminary data on corpora lutea of pregnancy give similar levels at the end of pregnancy $(129 \pm 19 \mathrm{fmol} / \mathrm{mg}$ protein, Day $19, n=7$; $144 \pm 23 \mathrm{fmol} / \mathrm{mg}$ protein on Day $20, n=4)$. The $K_{\mathrm{d}}$ values for $\left[{ }^{125} \mathrm{I}\right] \mathrm{ICYP}$ binding in membranes from regressing or regressed corpora lutea did not differ from $K_{d}$ values for binding to luteal 
membranes of pseudopregnancy (Table 1). In corpora lutea from PMSG-treated rats, the $\beta$ adrenergic receptor content on Day 2-3 was approximately 3-4-fold higher than in older corpora lutea (Day 7-11) (Fig. 1).

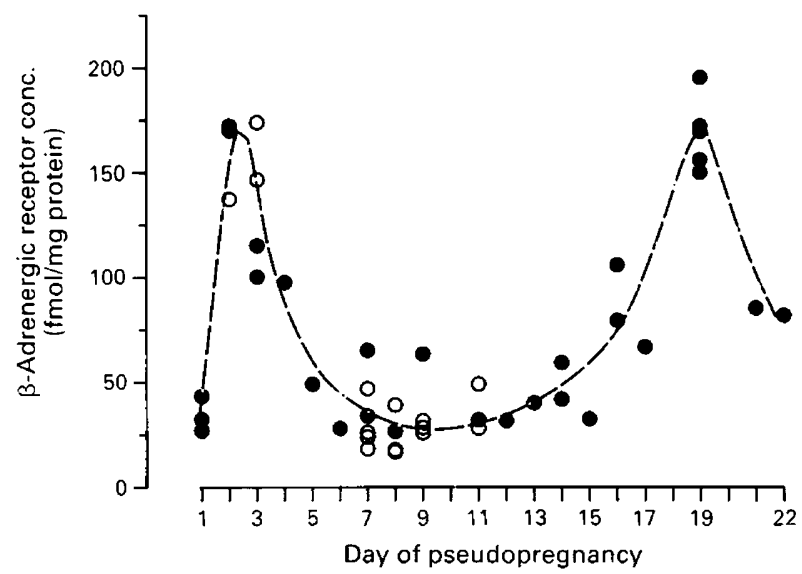

Fig. 1. Luteal $\beta$-adrenergic receptor concentration in the adult pseudopregnant rat ( $\bullet$ ) during the luteal phase (Day 1-11), luteolysis (Day 12-15) and after luteolysis (Day 16-22). In the figure are also given the luteal $\beta$-adrenergic receptor concentrations in PMSG-treated immature rats $(O)$ during the luteal phase. Each point demonstrates the calculated receptor concentration for one membrane preparation. Each membrane preparation was prepared from corpora lutea from $2-4$ rats. $K_{\mathrm{d}}$ values for $\left[{ }^{125} \mathrm{I}\right] \mathrm{ICYP}$ binding and mean $\beta$-adrenergic receptor content in corpora lutea of adult pseudopregnant rats are given in Table 1 . The $K_{d}$ values for the PMSGtreated rats were $21 \pm 2 \mathrm{nM}$. Membrane preparation, incubation conditions, separation of bound and free, calculation of receptor content and protein determination were as described in 'Materials and Methods'.

Table 1. Concentrations $\left(\mathrm{B}_{\mathrm{max}}\right)$ of $\beta$-receptors and $K_{\mathrm{d}}$ values for binding of $\left[{ }^{125} \mathrm{I}\right] \mathrm{ICYP}$ to membranes of corpora lutea from adult pseudopregnant rats of different ages

\begin{tabular}{llccc}
\hline $\begin{array}{l}\text { Day after } \\
\text { mating }\end{array}$ & $\begin{array}{l}\text { Type of } \\
\text { corpora lutea }\end{array}$ & $n$ & $\begin{array}{c}\mathrm{B}_{\max } \\
(\mathrm{fmol} / \mathrm{mg} \text { protein })\end{array}$ & $\begin{array}{c}K_{\mathrm{d}} \\
(\mathrm{pM})\end{array}$ \\
\hline $\mathrm{I}$ & Newly formed & 3 & $34 \cdot 2 \pm 4 \cdot 9$ & $30 \cdot 1 \pm 2 \cdot 0$ \\
$2-4$ & Early luteal & 5 & $131 \cdot 1 \pm 16 \cdot 7^{*} \dagger$ & $28 \cdot 0 \pm 2 \cdot 7$ \\
$5-11$ & Mid- and late & & & \\
& luteal phase & 7 & $41 \cdot 1 \pm 6 \cdot 8$ & $31 \cdot 6 \pm 3 \cdot 6$ \\
$12-15$ & Regressing & 5 & $40 \cdot 9 \pm 5 \cdot 0$ & $34 \cdot 5 \pm 4 \cdot 5$ \\
$16-22$ & Regressed & 10 & $126 \cdot 0 \pm 14 \cdot 9^{*} \dagger$ & $24 \cdot 5 \pm 2 \cdot 0$ \\
$26-28$ & Regressed & 3 & $66 \cdot 8 \pm 11 \cdot 0$ & $26 \cdot 0 \pm 4 \cdot 0$ \\
\hline
\end{tabular}

${ }^{*} \mathbf{P}<0.01$ vs Days 1, 5-11 and 12-15.

$\dagger P<0.05$ vs Days 26-28.

To determine the proportion of $\beta_{1}$ and $\beta_{2}$ subtype of the luteal $\beta$-adrenergic receptor during adult pseudopregnancy, competition studies were performed with subtype selective $\beta$-adrenergic receptor compounds. Two $\beta_{1}$-selective adrenergic antagonists (betaxolol and metoprolol) and one $\beta_{2}$-selective antagonist (zinterol) were used. The competition curves were compared with those of the heart, which contains a mixture of $\beta_{1}$ - and $\beta_{2}$-adrenergic receptors, and the uterus, which, in the 
rat, contains adrenergic receptors of subtype $\beta_{2}$. Analysis of the competition data indicated the presence of two binding sites with high and low $K_{\mathrm{i}}$-values in the heart, while only one binding site was seen for corpus luteum and uterus (Fig. 2; Table 2). The one site binding in the corpus luteum and uterus were seen at high $K_{\mathrm{i}}$-values for betaxolol and metoprolol, i.e. at about the same $K_{\mathrm{i}}$-value as for the $\beta_{2}$-adrenergic receptors in the heart with these drugs (Table 2). With the $\beta_{2}$-selective drug zinterol, the $K_{\mathrm{i}}$-values for the one site binding of the corpus luteum and uterus were in the same range as the low $K_{\mathrm{i}}$-component of the $\beta_{2}$-adrenergic receptor component in the heart for this drug (Table 2).

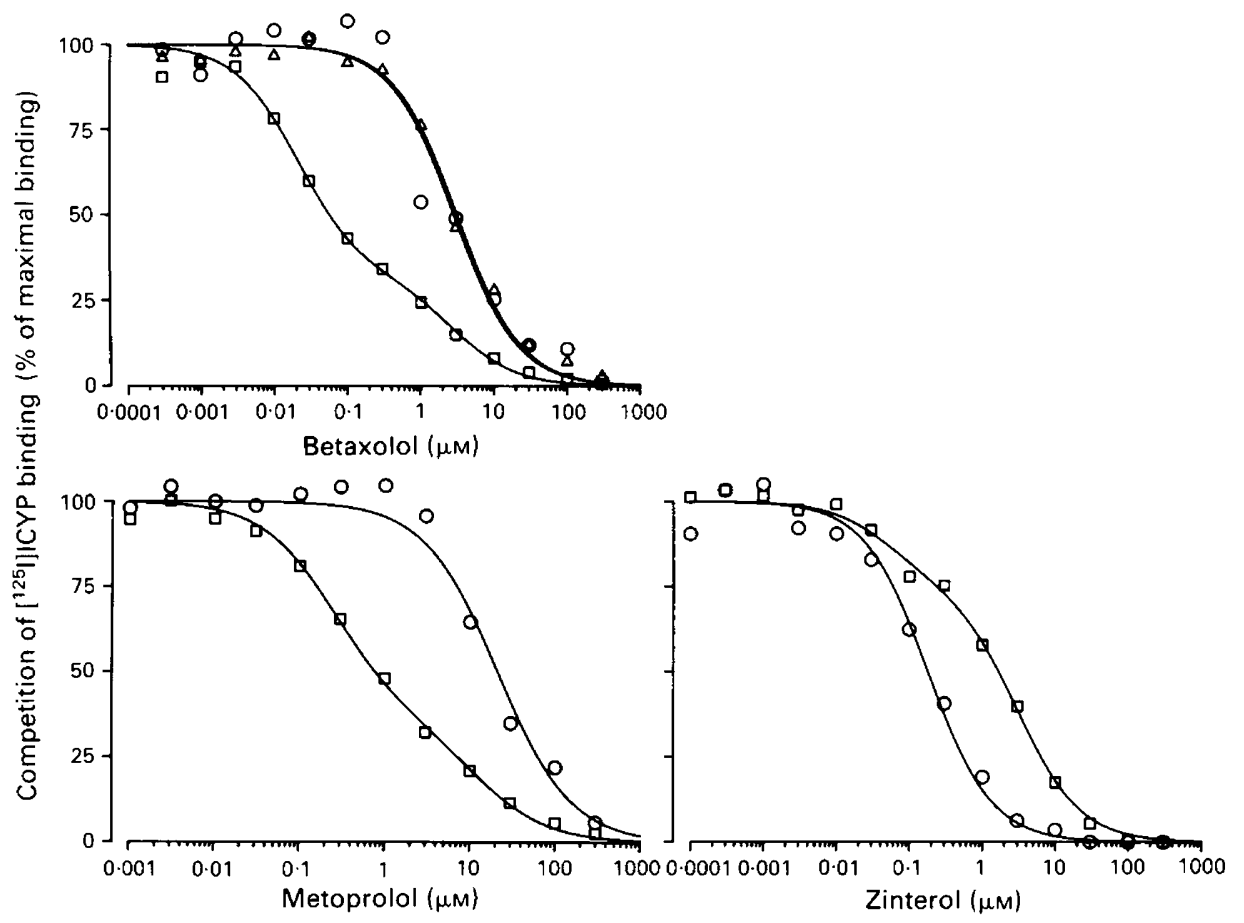

Fig. 2. Competition of binding of $100 \mathrm{pM}-\left[{ }^{125} \mathrm{I}\right] \mathrm{ICYP}$ with the selective $\beta$-adrenergic antagonists betaxolol $\left(\beta_{1}\right)$, metoprolol $\left(\beta_{1}\right)$ and zinterol $\left(\beta_{2}\right)$ in membranes of corpora lutea $(O)$, heart $(\square)$ and uterus $(\triangle)$ from PMSG-treated immature rats on Day 3. Each point is the mean of duplicate determinations. The data were fitted to a model with one or two affinity states and the $K_{\mathrm{i}}$ values are given in Table 2 .

The computer-derived competition curves are given in the figures with a two binding-site model for the heart $(P<0.01$ versus one binding site model), and with a one binding-site model for the uterus and corpus luteum.

Figure 3 shows the competition of $\left[{ }^{125} \mathrm{I}\right] \mathrm{ICYP}$ binding with betaxolol in membranes from a corpus luteum of Days 3, 8 and 15 in adult pseudopregnant rats and membranes of corpora lutea dissected after the luteolytic period (Day 19). Analysis of the competition data indicate that only one binding site was present in the corpora lutea of each age. The $K_{\mathrm{i}}$ values were the same for all ages, in the same range as the $K_{\mathrm{i}}$ value for the $\beta_{2}$-adrenergic receptor component in the rat heart.

\section{Discussion}

The present study provides detailed data on the properties of luteal $\beta$-adrenergic receptors in a physiological corpus luteum model, the adult pseudopregnant rat. The $\beta$-adrenergic receptor 
Table 2. $K_{\mathrm{i}}$ values for $\beta_{1}$ and $\beta_{2}$-selective adrenergic drugs

\begin{tabular}{|c|c|c|c|c|c|c|c|c|c|}
\hline & \multicolumn{3}{|c|}{ Betaxolol } & \multicolumn{3}{|c|}{ Metoprolol } & \multicolumn{3}{|c|}{ Zinterol } \\
\hline & $\begin{array}{c}K_{\mathrm{i} 1} \\
(\mathrm{nM})\end{array}$ & $\begin{array}{c}K_{\mathrm{i} 2} \\
(\mathrm{nM})\end{array}$ & $\begin{array}{c}\% \beta_{1} \\
\text { subtype }\end{array}$ & $\begin{array}{c}K_{\mathrm{i} 1} \\
(\mathrm{nM})\end{array}$ & $\begin{array}{c}K_{\mathrm{i} 2} \\
(\mathrm{nM})\end{array}$ & $\begin{array}{c}\% \beta_{1} \\
\text { subtype }\end{array}$ & $\begin{array}{c}K_{\mathrm{i} 1} \\
(\mathrm{nM})\end{array}$ & $\begin{array}{c}K_{\mathrm{i} 2} \\
(\mathrm{nM})\end{array}$ & $\begin{array}{c}\% \beta_{1} \\
\text { subtype }\end{array}$ \\
\hline Heart & $\begin{array}{c}6 \cdot 7 \pm \\
0 \cdot 3\end{array}$ & $\begin{array}{c}885 \pm \\
257\end{array}$ & $68 \frac{t}{7}$ & $79 \pm$ & $\begin{array}{c}3880 \pm \\
1552\end{array}$ & $63 \pm$ & $\begin{array}{c}994 \pm \\
149\end{array}$ & $18 \pm$ & $\begin{array}{c}76 \pm \\
19\end{array}$ \\
\hline Uterus & 一 $^{*}$ & $\begin{array}{c}662 \pm \\
51\end{array}$ & 0 & - & - & - & 一 $^{*}$ & $23 \frac{t}{2}$ & 0 \\
\hline Corpus luteum & - $^{*}$ & $\begin{array}{c}449 \pm \\
88\end{array}$ & 0 & - $^{*}$ & $\begin{array}{c}3432 \pm \\
549\end{array}$ & 0 & - $^{*}$ & $29 \frac{ \pm}{3}$ & 0 \\
\hline
\end{tabular}

*Only $\beta_{2}$-adrenergic receptor subtype detectable.

The data are compiled from Fig. 2, competition of the [ $\left.{ }^{125} \mathrm{I}\right] \mathrm{ICYP}$ binding with betaxolol, metoprolol and zinterol, respectively. The concentration of $\left.{ }^{125} \mathrm{I}\right] \mathrm{ICYP}\left(\mathrm{S}_{\mathrm{ICYP}}\right)$ was $100 \mathrm{pM}$ and the $K_{\mathrm{d}}$ values for $\left[{ }^{125} \mathrm{I}\right] \mathrm{ICYP}$ binding to rat heart, uterus and corpus luteum were $44 \pm 6,30 \pm 3$ and $20 \pm 3 \mathrm{nM}$, respectively. The competition data were fitted to 2 -site binding curves for calculation of $\mathrm{IC}_{50}$-values. The $K_{\mathrm{i}}$ values were calculated from the $\mathrm{IC}_{50}$-values with the formula: $K_{\mathrm{i}}=\mathrm{IC}_{50} /\left(1+\mathrm{S}_{\mathrm{ICYP}} / K_{\mathrm{d}}\right)$.

concentration in corpora lutea of pseudopregnancy varies markedly with the functional age of the corpus luteum while the subtype of the $\beta$-adrenergic receptor is unchanged during the same period.

Studies on the $\beta$-adrenergic receptor subtype in different rat corpus luteum models, e.g. in luteinized ovaries, in granulosa cells luteinized under culture conditions and in isolated corpora lutea, indicate that the $\beta$-adrenergic receptor in these models is mainly of the subtype $\beta_{2}$ (Coleman et al., 1979; Adashi \& Hsueh, 1981; Norjavaara et al., 1984). In these studies, the subtype has been determined by the response or displacement order of isoproterenol, adrenaline and noradrenaline according to the classical criteria of Lands et al. (1967). However, in these types of experiments only the dominant $\beta$-adrenergic receptor subtype can be determined and not the eventual presence of a second subtype. Recent advances and availability of selective $\beta$-adrenergic receptor antagonists provide an opportunity to determine the relative proportion between the subtypes (DeLean $e t$ al., 1980). The present study demonstrates for the first time that the subtype of the $\beta$-adrenergic receptor is exclusively $\beta_{2}$ in the corpus luteum of the rat during pseudopregnancy. Furthermore, the subtype does not change during pseudopregnancy and at least up to 1 week after functional luteolysis. In line with this finding, it has been shown that the subtype of the $\beta$-adrenergic receptor is an intrinsic property of the gene product and is not the result of a post-translational modification of the receptor by the cell in which it is expressed (Strader et al., 1987). Since adrenaline is supposed to act on $\beta_{2}$-adrenergic receptors, i.e. on classical hormone receptors, and noradrenaline is believed to act on $\beta_{1}$-receptors, i.e. on neural receptors (Ariens \& Simonis, 1983), our findings indicate that circulating adrenaline can act as a physiological hormone in rat corpora lutea.

For the corpus luteum of the rabbit and pig the subtype of the $\beta$-adrenergic receptor is predominantly $\beta_{1}$ (Abramowitz et al., 1982; Perkins et al., 1986). The reason for this difference in subtype between these species and the rat is at present unknown.

In the newly formed corpora lutea (Day 1) the $\beta$-adrenergic receptor concentration is comparable to that of the non-luteal ovary (Aguado et al., 1982; Norjavaara et al., 1984). On the 2 nd day of pseudopregnancy the luteal $\beta$-adrenergic receptor concentration increased dramatically, $\sim 3$-fold, and remained high for another day, whereafter the concentration declined. This pattern of $\beta$-adrenergic receptor concentration during pseudopregnancy in adult rats is similar to that of the PMSG-treated immature rat (Norjavaara et al., 1984; present study).

The physiological role of $\beta$-adrenergic receptors in the corpus luteum is still essentially unknown, despite numerous efforts over the past decade (Spicer, 1986). However, it is well established that $\beta$-adrenergic receptors in the corpus luteum are functionally coupled to adenylate cyclase and progesterone synthesis (Spicer, 1986). It is also known that newly formed rat corpora 


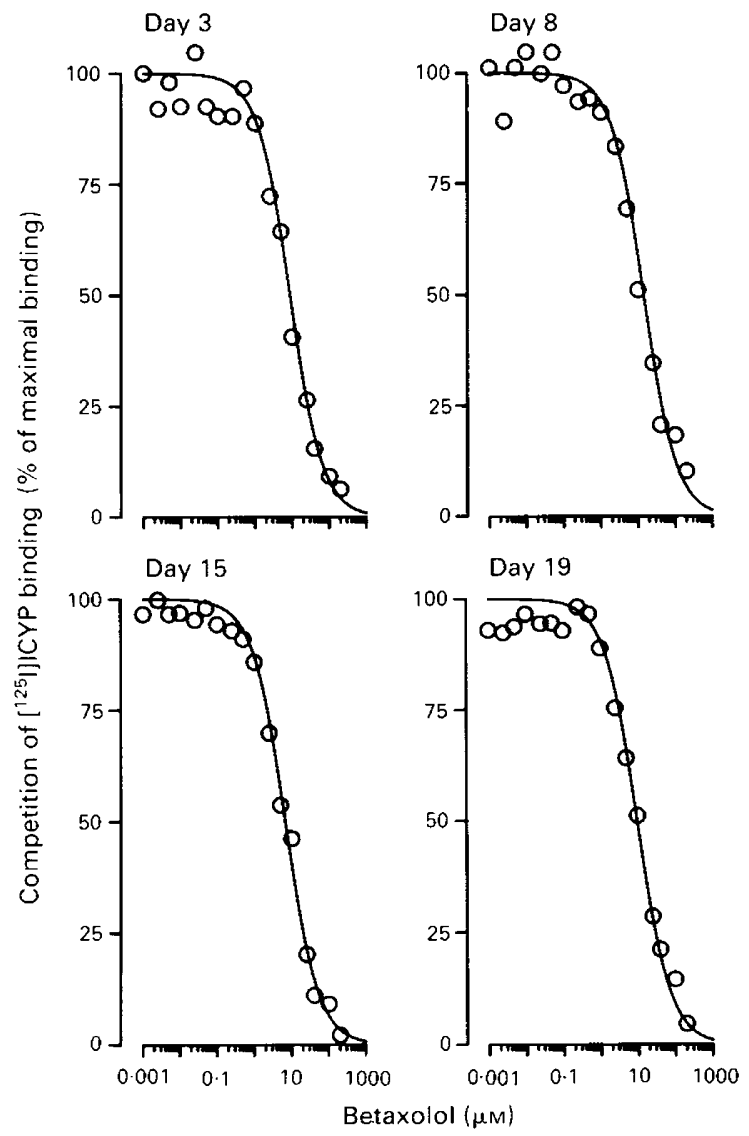

Fig. 3. Competition of $100 \mathrm{pM}-\left[{ }^{125} \mathrm{I}\right] \mathrm{ICYP}$ binding with the $\beta_{1}$ selective adrenergic antagonist betaxolol in membranes of corpora lutea from adult pseudopregnant rats during the early and mid-luteal phases (Days 3 and 8, respectively), during and after luteolysis (Days 15 and 19, respectively). Each point is the mean of duplicate determinations. The data were fitted to a binding model with two affinity states and the computer-derived competition curves are given in the figure. The calculated $K_{\mathrm{i}}$ values for Day 3,8,15 and 19 were $2005 \pm 211,3239 \pm 546$, $1528 \pm 136$ and $2204 \pm 440 \mathrm{nM}$, respectively.

lutea need support from substances other than LH (Rothchild, 1981). Prolactin is known to convert the corpus luteum of the oestrous cycle into one of pseudopregnancy or pregnancy by promoting the development of $\mathrm{LH}$ receptors (Richards \& Williams, 1976). The rapid increase in $\beta$-adrenergic receptors could indicate that catecholamines assist prolactin in the rescue of the corpus luteum of the oestrous cycle, e.g. by promoting progesterone synthesis during the early phase of pseudopregnancy when LH and oestradiol receptor levels are known to be low (Richards, 1974; Richards \& Midgley, 1976). The circulating concentrations of adrenaline and noradrenaline in plasma are comparable to those known to stimulate progesterone synthesis in vitro by luteal cells (Norjavaara, 1984). Furthermore, the stimulatory effect of catecholamines on luteal adenylate cyclase activity is maximal on Day 2-3 in the PMSG-treated rats and, during this period, even greater than the response to LH (Rosberg et al., 1986; Selstam et al., 1987).

The corpus luteum model used in the present study, i.e. corpora lutea from pseudopregnant adult rats, is unique in the sense that the corpora lutea can be followed over a long period of time, extending over and beyond the luteolytic period. After the initial peak in $\beta$-adrenergic receptor levels, the levels decreased and were steady throughout pseudopregnancy, in analogy with the 
PMSG model (Norjavaara et al., 1984). The concentrations were also unchanged during spontaneous luteolysis in our model, as found after PGF- $2 \alpha$-induced luteolysis (Norjavaara \& Rosberg, 1986). However, about 1 week after the functional luteolysis a surprising second increase in $\beta$-adrenergic receptor levels was seen. This increase occurs after the rats have started to cycle again. The reason for and role of this second $\beta$-adrenergic receptor peak is even more difficult to explain than the first peak. However, one can imagine that the corpus luteum of pseudopregnancy is preprogrammed for a longer period than the actual pseudopregnancy, and some processes may continue even after functional luteolysis. The appearance of a second $\beta$-adrenergic receptor peak in regressing corpora lutea on Day 19-20, corresponding to a few days before the time of normal parturition in pregnant rats, is therefore of interest. Preliminary data on pregnant rats indicate levels of $\beta$-adrenergic receptors on Day 19-20 that are similar to those in the pseudopregnant rats.

The signal initiating luteal regression is now fairly well known. However, the mechanism(s) responsible for the structural regression are much less studied. Recent data indicate that the structural regression is an active process, involving among others changes in membrane fluidity (Carlson et al., 1984), as well as invasion of macrophages producing cytokines (Bagavandos et al., 1988). The transient increase of $\beta$-adrenergic receptor concentrations during the post-luteolytic period may also play an as yet unidentified role in the morphological regression of the corpus luteum of pseudopregnancy.

The work was supported by grants from the Swedish Medical Research Council (04X-5653, 04X-27), Gunvor and Josef Anér Foundation, the Swedish Medical Society, the Göteborg Medical Society, Stiftelsen Handlanden Hjalmar Svenssons Forskningsfond, Åke Wibergs stiftelse, T. A. A. Amundsons Fond and the Medical Faculty of the University of Göteborg and Umea. We thank AB Hässle (Mölndal, Sweden) for alprenolol and metoprolol; Bristol-Myers company (Evansville, Indiana, USA) for zinterol; Ciba-Geigy Läkemedel AB (Västra Frölunda, Sweden) for phentolamine; and G. D. Searle AB (Malmö, Sweden) for betaxolol.

\section{References}

Abramowitz, J., Iyengar, R. \& Birnbaumer, L. (1982) Guanine nucleotide and magnesium ion regulation of the interaction of gonadotropic and $\beta$-adrenergic receptors with their hormones. A comparative study using a single membrane system. Endocrinology 110, 336-346.

Adashi, E.Y. \& Hsueh, A.J.W. (1981) Stimulation of $\beta_{2}$ adrenergic responsiveness by follicle-stimulating hormone in rat granulosa cells in vitro and in vivo. Endocrinology 108, 2170-2178.

Aguado, L.I., Petrovic, S.L. \& Ojeda, S.R. (1982) Ovarian $\beta$-adrenergic receptors during the onset of puberty: characterization, distribution and coupling to steroidogenic response. Endocrinology 110, 1124-1132.

Ariens, E.J. \& Simonis, A.M. (1983) Physiological and pharmacological aspects of adrenergic receptor classification. Biochem. Pharmacol. 32, 1539-1545.

Azhar, S. \& Menon, K.M.J. (1981) Receptor-mediated gonadotropin action in the ovary. J. biol. Chem. 256, 6548-6555.

Bagavandos, P., Kunkel, S.L., Wiggins, R.C. \& Keyes, P.L. (1988) Tumor necrosis factor $-\mathrm{a}$ (TNG $-\mathrm{a})$ production and localization of macrophages and $\mathbf{T}$ lymphocytes in the rabbit corpus luteum. Endocrinology 122, 1185-1187.
Carlson, J.C., Buhr, M.M. \& Riley, J.C.M. (1984) Alterations in the cellular membranes of regressing rat corpora lutea. Endocrinology 114, 521-526.

Cheng, Y.C. \& Prusoff, W.H. (1973) Relationship between the inhibition constant $\left(\mathrm{K}_{\mathrm{i}}\right)$ and the concentration of inhibitor which causes 50 per cent inhibition $\left(\mathrm{IC}_{50}\right)$ of an enzymatic reaction. Biochem. Pharmacol. 22, 3099-3108.

Coleman, A.J., Paterson, D.S. \& Somervill, A.R. (1979) The $\beta$-adrenergic receptor of rat corpus luteum membranes. Biochem. Pharmacol. 28, 1003-1013.

DeLean, A., Stadel, J.M. \& Lefkowitz, R.J. (1980) A ternary complex model explains the agonist-specific binding properties of the adenylate cyclase-coupled betaadrenergic receptor. J. biol. Chem. 255, 7108-7117.

Gåfvels, M., Selstam, G. \& Damber, J.-E. (1987) Influence of oxygen tension and substrates on basal and luteinizing hormone stimulated progesterone production and energy metabolism by isolated corpora lutea of adult pseudopregnant rats. Acta physiol. scand. 120, 475-482.

Harwood, J.P., Richert, N.D., Dufau, M.L. \& Catt, K.J. (1980) Gonadotropin-induced desensitization of epinephrine action in the luteinized rat ovary. Endocrinology 107, 280-288. 
Lands, A.M., Arnold, A., McAuliff, J.P., Luduena, F.P. \& Brown, T.C., Jr (1967) Differentiation of receptor systems activated by sympathomimetic amines. Nature, Lond. 214, 597-598.

Lowry, O.H., Rosebrough, N.J., Farr, A.L. \& Randall, R.J. (1951) Protein measurement with the Folin reagent. J. biol. Chem. 193, 265-275.

McIlroy, P.J. \& Bergert, E.R. (1984) Studies concerning a GTP regulatory subunit of rat luteal adenylate cyclase. Archs Biochem. Biophys. 233, 652-660.

McIntosh, J.E.A. \& McIntosh, R.P. (1980) Mathematical Modelling and Computers in Endocrinology (Monographs on Endocrinology. 16), 143-170. SpringerVerlag, Berlin.

Norjavaara, E. (1984) Influence of catecholamines on corpus luteum function. A study on corpora lutea of different ages and preovulatory granulosa cells of the rat. Ph.D. thesis, University of Göteborg.

Norjavaara, E. \& Rosberg, S. (1986) Mechanism of action of prostaglandin $F_{2 a}$-induced luteolysis: evidence for a rapid effect on the guanine nucleotide binding regulatory component of adenylate cyclase in rat luteal tissue. Molec. cell. Endocrinol. 48, 97-104.

Norjavaara, E., Selstam, G. \& Ahrén, K. (1982) Catecholamine stimulation of cyclic AMP and progesterone production in rat corpora lutea of different ages. Acta endocr., Copenh. 100,613-622.

Norjavaara, E., Selstam, G., Damber, J.-E. \& Johansson, B.-M. (1983) In vivo effect of noradrenaline on the cyclic AMP level in rat corpora lutea. Acta physiol. scand. 119, 113-116.

Norjavaara, E., Rosberg, S., Gåfvels, M. \& Selstam, G. (1984) $\beta$-adrenergic receptor concentration in corpora lutea of different ages obtained from pregnant mare serum gonadotropin-treated rats. Endocrinology 114, 2154-2159.

Norjavaara, E., Olofsson, J. \& Gåfvels, M. (1987) Redistribution of ovarian blood flow after injection of human chorionic gonadotropin and luteinizing hormone in the adult pseudopregnant rat. Endocrinology 120, 107-114.
Perkins, S.N., Cronin, M.J. \& Veldhuis, J.D. (1986) Properties of $\beta$-adrenergic receptors on porcine corpora lutea and granulosa cells. Endocrinology 118, 998-1004.

Richards, J.S. (1974) Estradiol binding to rat corpora lutea during pregnancy. Endocrinology 95, 10461053.

Richards, J.S. \& Midgley, A.R., Jr (1976) Protein hormone action: a key to understanding ovarian follicular and luteal cell development. Biol. Reprod. 14, 82-94.

Richards, J.S. \& Williams, J.J. (1976) Luteal cell receptor content for prolactin (PRL) and luteinizing hormone (LH): regulation by LH and PRL. Endocrinology 99, 1571-1581.

Rosberg, S., Norjavaara, E., Sender Baum, M. \& Khan, I. (1986) Adenylate cyclase activity in rat corpora lutea evidence for a rapid development of the regulatory $\mathrm{N}_{\mathrm{s}}$-protein. Acta endocr., Copenh. 112, 565-570.

Rothchild, I. (1981) The regulation of the mammalian corpus luteum. Recent Progr. Horm. Res. 37, 183-284.

Selstam, G., Gåfvels, M., Norjavaara, E. \& Damber, J.-E. (1985) Acute increase of noradrenaline on vascular resistance in the corpus luteum of the pseudopregnant rat. J. Reprod. Fert. 75, 351-356.

Selstam, G., Norjavaara, E., Rosberg, S., Khan, I., Hamberger, B. \& Hamberger, L. (1987) Catecholamine content and adenylate cyclase activity in corpora of different ages of the PMSG-treated immature rat. Molec. cell. Endocrinol. 53, 155-160.

Spicer, L.J. (1986) Catecholaminergic regulation of ovarian function in mammals: current concepts. Life Sci. 39, 1701-1711.

Strader, C.D., Candelore, M.R., Rands, E. \& Dixon, R.A.F. (1987) $\beta$-adrenergic receptor subtype is an intrinsic property of the receptor gene product. Molec. Pharmacol. 32, 179-183.

Woolf, C.M. (1968) Principles of Biometry. D van Nostrand Company Inc., Princeton.

Received 10 October 1988 